\title{
A REVIEW OF ADVANCES IN TUSSOCK GRASSLAND
}

L. W. McCASKILL, Tussock Grasslands and Mountain Lands Institute, Lincoln

In September 1962 the Tussock Grasslands and Mountain Lands Institute produced a Directory of Research listing projects and personnel concerned with the tussock grasslands and mountain lands. The number of people involved was about 100 and the number of separate projects more than 150. It is obvious that, in trying to survey advances being made in the tussock grasslands, I cannot mention more than a few of these workers. Failure to mention them does not mean that I do not appreciate the value of their work; merely that a paper such as this should be more than just a catalogue.

Everyone has his own definition of tussock grassland and the area involved, but I am discussing some $11,000,000$ acres, mainly in the South Island, carrying about two and a half million sheep and 40,000 cattle and having an importance to the New Zealand economy which cannot be. assessed in stock numbers alone. In sheep equivalents these lands could be claimed to carry about one to four acres but in places so much of the area is devoid of vegetation that stocking rates in the conventional sense mean little. Wool is the basic product, yielding at least 80 per cent of the gross return, and the flocks consist of over half Merinos, a little less than one-third half-breds, and one-sixth Corriedales.

I propose to review only some of the advances made since 1950.

In that year a statement was made at this Association's conference that "to New Zealand as a whole the tussock grasslands are of value for one purpose only, that is, the feeding of livestock". That statement went unchallenged. I think most people in New Zealand would now agree on the importance of the tussock grasslands from the point of view of soil and water conservation, of their value in regulating stream-flow for stock water on the plains, for the generation of hydro-electricity, and for irrigation.

Another statement made was not challenged either. I quote: "It is, however, necessary to consider carefully whether or not a legume should be introduced into unploughable tussock country. 
That it is possible has been demonstrated on a number of occasions. It is, however, doubtful if it is advisable. It is unlikely to be profitable. ..."

The year 1950 is also important because by then the trials on aerial sowing of seed and fertiliser organised and financed by the Soil Conservation and Rivers Control Council, urged on by D. A. Campbell, had culminated in the organisation of aerial farming on a large scale. Two early happenings in this respect were of significance to the tussock grasslands. In 3948 A. M. Prichard dropped grass seed from a plane on 100 acres of Te Akatarawa, Waitaki Valley, and in March 1949 C. Brazier of Airwork, Christchurch, completed a contract to sow from the air three tons of fertiliser on tussock country on Banks Peninsula.

\section{Rabbits}

It was the use of the aeroplane for rabbit poisoning rather than for seeding and topdressing which made possible what have been really dramatic changes in the tussock grasslands. Of the 40,000 tons of poisoned baits dropped since 1950 (including 5,197 tons in 1962), a very large portion was used on tussock country.

Without the "killer and devaluation" policy of the Rabbit Destruction Council, aided by the technique of aerial poisoning, advances in the tussock economy must inevitably have been slow and laborious.

'Warner (1956) made a survey of the effect of rabbit destruction accelerated by the use of the new aerial tool. From 17 runs in Central Otago of an area of 264,000 acres he produced the following figures:

$\begin{array}{lccc} & \text { Sheep wintered } & \text { Wool } & \text { Rabbits killed } \\ 1948 & 51,500 & 371,000 & 750,000 \\ 19.54 & 60,200 & 503,000 & 100,000\end{array}$

Some idea of the effects on the national scale is given by the export figures :

$\begin{array}{ccc} & \text { Rabbit skins } & \text { Rabbit carcasses } \\ 1948 & 13,500,000 & 5,000,000 \\ 1955 & 760,000 & 420,000\end{array}$

While admiring the Rabbit Destruction Council for its remarkable achievements, we must regret that we have been unable to , reduce our annual expenditure below $£ 1 \frac{1}{4}$ million and that we still have too many rabbits in too many places. We need an advance in rabbit destruction comparable with that of 1950. 


\section{Land Tenure}

The period under review begins about the time when the Department of Lands and Survey, responsible for leasing the larger part of the land under tussock, proceeded to implement the provisions of the 1948 Land Act. This provided for security of tenure through the granting of "pastoral leases" of 33 years with perpetual right of renewal, subject to stock limitation, over the more stable land. It provided also for "pastoral occupation licences" for short terms, with no right of renewal, over such areas as we call Class VIII land today. In the light of present knowledge of catchment requirements, it is unfortunate that on reassessment the granting of new leases under the Act has been made almost entirely under pastoral lease. This can cause difficulties if and when we get down to planning rational land use. As against this, the granting of security of tenure gave new heart to Crown tenants and provided the basis for much of the improvement made over very large areas of tussock grasslands.

\section{High-altitude Grasslands}

The Tussock Grassland Research Committee were particularly concerned with the area which I suggest might preferably have been leased under pastoral occupation licence. In their report (1954) they summarised what was known at the time of the scientific aspects of the high-altitude snow-tussock. grassland. Because of the inherent instability and the advanced state of deterioration they urged that, pending the results of research aimed at rehabilitation, every effort should be made to reduce burning and grazing. Widely criticised at the time, the findings of the Committee have subsequently proved to be justified. Most of their suggestions for research have been implemented and some of the projects are mentioned in this review.

\section{Nomenclature}

It is a fundamental requirement for study and experiment that we should know what we are studying. Difficulties in the tussock grasslands in this respect have occurred mainly with the snow grasses. Some resolution of these difficulties has resulted from the intensive efforts which enabled Zotov to complete his work on Danthonia and Arundo in time for publication in the first issue of the New Zealand Journal of Botany (Zotov 1963). Far-reaching changes in nomenclature have been made in the 60-page revision and these will require considerable study by workers in the tussock grasslands: "The New Zealand species of A rundo are transferred to Cortuderia, which is placed in the new tribe Corta- 
derieae, while those of Danthonia are grouped in the new genera Chionochloa, Notodanthonia, Erythranthera, and Pyrrhanthera and placed in the newly characterised tribe Danthonieae. All these, together with certain introduced species, are included in the subfamily Arundinoideae".

\section{Description of the Vegetation}

Space permits mention of only two studies. In the first, Barker ( 1953) made a detailed ecological study of a 5,000-acre sheep run in South Canterbury. Floristic analysis showed that "after nearly a century of modification under pastoral use, two principal rather homogeneous plant communities are now present, each with its own characteristic combination of species". This study has exerted considerable influence, partly because it used the concepts and methods of the Zurich-Montpellier school of phytosociology, and partly because of what is "now called the "Barker Line" in connection with the importance or otherwise of Celmisia spectabilis in the community.

Connor (1960) drew attention to the importance of Festuca matthewsii as a species characteristic of a type of snow tussock grassland not previously recognised as distinct. He showed that this tussock which is "palatable to sheep and is always grazed, often quite hard," can be a valuable indicator plant. He made it clear, too, that the complexity of snow grass associations, while posing a problem for botanists, provides an equally difficult problem for land users when it comes to management.

In another paper Connor ( 1961), using a method of sociological analysis, describes a snow tussock community in the Lindis Pass area where Festuca matthewsii is a characteristic species. In addition to showing the place of this tussock in the overall picture of the grassland, Connor has set a standard of description and analysis which must have great influence on future ecological investigations.

\section{Climate}

Until A. F. Mark, in connection with his long-term study of the autecology of snow grass, established 15 climatic stations on the Old Man Range in Central Otago (Mark 1962), and thus made a major advance in climatology in New Zealand, we had no detailed climatic records from any mountain areas. Mark recorded precipitation, air and soil temperatures, wind speed, evaporation, soil moisture, and general weather conditions in the major vegetation types. He has shown that "the present climatic pattern can be readily correlated with the zonation pattern of the vegeta- 
tion". His climatic records there and on Coronet Peak and Maungatua have already proved a useful guide in the planning of further climatic studies by the Forest and Range Experiment Station, Rangiora, and the Plant Physiology Division of the Department of Scientific and Industrial Research.

\section{Soil Biology}

Our knowledge of the biology of at least three tussock grassland soils was greatly increased by the publication of a series of 18 papers in the New Zealand Journal of Agricultural Research between 1958 and 1960. Among these papers was one on earthworms by K. E. Lee, who in a major publication has since added vastly to our knowledge (Lee 1959). He stresses that under sparse cover, so common in the depleted areas, the earthworms are concentrated under individual plants and they are lacking where cover'is absent. Restoration of cover is basic to the restoration of the beneficial effects of a high population of earthworms, but we cannot hope for this until we can restore a full organic cycle.

The work of Stockdill (1959) indicates that where we develop tussock grassland into a highly improved condition, we should consider the cultivation of earthworms to aid such a cycle. We might even aim at the 400,000 earthworms per acre which W. W: Smith in 1887 recorded in one area of tussock grassland!

An outstanding contribution to our knowledge of the soil microflora has been made by Robinson (1962) as a result of his studies of a virgin tussock grassland Craigieburn soil in the Castle Hill basin, Canterbury. He found that in this typically infertile and unproductive soil "the nitrifying bacteria, usually considered nearly ubiquitous in soils, existed in this soil in extremely small numbers because of the limited amount of energy-yielding substrate available to them. The sulphur-oxidising autotrophs were also absent, presumably because of the small quantities of reduced sulphur compounds occurring in this soil".

Robinson comments on the fact that so much of the past work on the soil micro-flora has been concerned with soils receiving large applications of fertility-building materials.

Developing Robinson's thesis, O'Connor, Robinson, and Jackman (1962), dealing with the same soil, stress the fact that apparently negligible mineralisation effects obtained after cultivation of this unimproved grassland "are, agronomically at least, in striking contrast to the crop-growth conditions observed after cultivation of limed, topdressed, and legume-rich grasslands developed on the same soil".

From the practical point of view they suggest that primary cultivation of a grassland on such low-fertility, acid soil to initiate 
improvement may not be warranted if legume establishment and dominance can be more cheaply obtained by aerial oversowing or sod seeding. Cultivation, once the soil has been enriched by more decomposable residues, "could promote active mineralisation with resultant benefit to grasses or crops sown in prepared seedbeds".

This work must provide thought for those planning long-term improvement programmes in the tussock grasslands.

\section{Insects}

Kelsey (1957) listed 45 insects that feed on roots or aerial parts of tussock species. He considered, in general, that the leafeating insects helped in producing seedbeds in the centres of tussocks and that the major damage was caused by the root eaters. He recorded up to 47 larvae under a single tussock and showed how the movement of these through the soil made the top layer increasingly liable to the effects of frost action and wind erosion.

It is regrettable that Kelsey was unable to continue his experimental work, but, in a personal communication, he has summarised his views on the present situation. These are based on field observation over 15 years.

He says that $\mathbf{O x y c a n u s}$ can be responsible for the complete loss of inter-tussock growth and can entirely prevent the establishment of seedlings. Grass grubs have similar effects and in addition, because of their physical effects, contribute largely to the production of bare soil. "It is not generally recognised that a relatively few grass grubs or caterpillars can, without altering pasture composition, reduce available grazing to a very low level." . . "While it is true that there are big gaps in our knowledge of entomological aspects of tussock grassland development, there is ample evidence that in DDT at $2 \mathrm{lb}$ per acre there is available, at low cost, a solution for the control of the four main insect pests -grass grubs, Oxycanus, Persectania, and Crambus. It is felt that, now that rabbit control has been achieved, these insects constitute probably the most important single factor preventing establishment of continuous vegetative cover on much of our tussock grassland."

The only other advance in entomological knowledge is that due to E. G. White, who, financed partly by the Institute, has undertaken a comprehensive survey and investigation of the insect fauna of some areas of tussock. grassland. In one area of less than 10 square miles containing associations of snow grass and of silver, blue and hard tussocks, with the altitude ranging from 2,000 to $4,500 \mathrm{ft}$ and an average rainfall from 40 to $50 \mathrm{in}$, he has collected approximately 1,000 species of insects. He has obtained informa- 
tion on the status of many individual species, an important step in the understanding of whether they are likely to be of economic importance. This project, the first intensive study in New Zealand of the insect fauna of a grassland area, should prove of further value in that the area includes both improved and unimproved tussock grassland.

\section{Soil Classification}

With the meeting in New Zealand in November 1962 of Commissions IV and V of the International Society of Soil Science such full publicity was given to soil classification and the work of the Soil Bureau of the Department of Scientific and Industrial Research that I can add nothing here of interest or value. I must, however, pay tribute to the tremendous help that the Soil Bureau and individual members of its staff have been to workers in the tussock grasslands in the period under review. I must refer also to a few publications which have been major advances as far as understanding tussock soils is concerned: Taylor and Cox (I 956) placed the soils of the tussock grasslands into easily understood relationship with the remainder of the soil pattern; Taylor and Pohlen ( 1962) with a handbook for the field study of New Zealand soils have enabled all workers to use a uniform terminology and set of standards for describing, classifying and mapping our soils and incidentally given us a complete summary of the New Zealand Genetic Soil Classification; the printing of the provisional four-miles-to-the-inch soil map of the South Island and the tentative legend accompanying it provide a soil picture in broad terms of any area under study.

\section{Soil-frost Action}

Gradwell, in a series of papers (for example Gradwell 1962), has stressed the fundamental importance of vegetation in reducing and even preventing the effects of soil-frost action.

He has shown how a continuous ground cover of plants provides complete protection and how even a small amount of overhanging foliage reduces the growth of ice needles in the soil below.

Where the plant cover has been removed a layer of tussock litter from $\frac{1}{2}$ to $2 \mathrm{in}$. deep can protect the soil below from severe frost action. He considers that complete protection can probably be obtained by a cover of plants or of litter much reduced in amount compared with the original closed cover of snow tussocks.

Gradwell's work is so illuminating as regards the importance of cover, he would be a bold man who, having read his papers, would light a tussock fire without being certain that by proper grazing management and spelling or by oversowing and fertilising 
he could ensure sufficient cover before the following winter to protect the soil against frost action.,

\section{Land Capability}

The period under review saw the introduction by the Soil Conservation and Rivers Control Council of the American system of land capability classification. It has been widely applied by soil conservators of the Soil Conservation and Rivers Control Council (since 1955 of the Department of Agriculture) and of catchment authorities. Approximately half of the tussock grassland has been covered in more or less detail under this system and it is the basis for the preparation of conservation run plans under which improvement involving soil conservation is subsidised.

The system was developed in America largely for areas under a crop-land economy and is not ideally suited to a country mainly under pasture. O'Connor (1962) has pointed out weaknesses in the system as used in New Zealand, claiming that it is "by itself a poor guide to recommended use". While admitting that the weaknesses are largely overcome in practice by soil conservators, he considers we should aim at a more systematic understanding regarding the suitability of mountain soils "for different kinds of use and for different intensities of use of different kinds".

Analysing our experience in pastoral use and in experimentation over 100 years, he has produced a summary of typical South Island mountain soils, rated them for stabilisation and production, and classified them for pastoral suitability at five different levels of culture. He stresses the major importance of fertility in the maintenance or replacement of a mantle of vegetation and suggests "that perhaps a high level of cultural intensity may be necessary in the high-altitude zone, even for purely conservation objectives".

From the points of view of the long-term pastoral use of the tussock grasslands, coupled with soil and water conservation, O'Connor's views should be given the most careful attention by runholders, farm advisers, soil conservators, and administrators of land. He makes it clear that, to enable sound run plans to be formulated, the ratepayer and taxpayer may well be asked to help pay for the development of some soils at a high cultural intensity so that maximum off-site benefits be obtained at the same time as the pastoral industry continues.

In connection with any possible implementation and extension of O'Connor's suggestions, attenion is drawn to some ideas of Cutler ( 1962). Deploring the fact that of "many land development projects under way or proposed, it is unfortunately true that few are planned in terms of the national resources of soil. It is rare 
that technical advice is sought before development starts", Cutler has developed a system of soils according to their "potential capability and limitations based on the Four-mile Reconnaissance Survey and the genetic classification. Cutler divides soils into five soil-capability classes and claims his system "provides a basis for the assessment of the most economic use of land". He found his system to work in well with land capability as practised by soil conservators.

Still on this theme: Leamy (1962) has demonstrated a method of correlating soil classification and soil capability in the Upper Clutha Valley. This method does not reveal any new information about soils, but soils can be arranged in groups about which generalisation on land use may be made and the edaphic potential of the soils of a given region may be compared.

It also offers objective means of assessing soil in the process of the valuation of land. The scheme in short "provides a useful tool for detailed land-use planning". In attempts to develop an overall land assessment, Leamy says, there is a place for both soilcapability and land-capability classification.

The most comprehensive maps of land-capability classes so far published in New Zealand are a 16-miles-to-the-inch map of Canterbury by Dunbar (1962) and 60-miles-to-the-inch provisional maps of North and South Islands in the report of the Soil Conservation and Rivers Control Council for the year ended 31 March 1963.

Whatever its minor deficiencies, the present system of landcapability mapping does provide us with a means whereby people working in a great variety of disciplines can look at land and its use with a common eye with a view to planning for use in perpetuity.

\section{Condition and Trend}

While assuming that the eventual proper use of tussock grasslands can be reached only after standards based on vegetative response to grazing are set to maintain a safe balance between soil stability, vegetative production, and animal use. Riney and Dunbar (1956) considered the most urgent need was to meet minimum requirements for conservation. Such requirements imply the maintenance of a soil-vegetation balance and the prevention of further depletion of existing soil and vegetation. In their publication a series of photographs with description provides evidence useful in recognising the status of an area in terms of its conservation requirements. A study of such evidence is vital to the development of management practices which will maintain stability and improve 
production where the soil-vegetation balance is satisfactory; and where it is unsatisfactory, will be such as to ensure a trend towards satisfactory condition. This idea that standards for land use must be based on and conform to conservation requirements was a marked advance in thinking on tussock grasslands. It is regrettable that up to the present it has not been used to a much greater extent.

In this connection it is perhaps worth reminding you of a statement on range condition by Kenneth W. Parker, an American, at the 6th International Grassland Conference.

"Range condition is the health or status of the range, and a range in the most robust health or highest status is one which has been grazed by livestock on a sustained-yield basis and which is in an optimum state of soil stability and quality and has the highest possible development of vegetation under the prevailing climate,"

We should not aim at any lower status for our own tussock grasslands.

\section{Sod-seeding or 0 verdrilling}

The great success attached to the practice of aerial seeding and topdressing has tended somewhat to relegate to the background the problem of rehabilitating depleted areas in the semiarid zones and in areas in the sub-humid zone where the rainfall is at the lower end of the scale. In these areas establishment of cover by aerial seeding is very difficult and we have had to rely largely on mechanical introduction. Over 6,000 acres have been seeded in this way in the Waitaki basin by the Catchment Commission's unit alone, and a similar area has been covered with Catchment Board equipment in Central Otago. The techniques learned in these areas will prove valuable for introducing highquality grasses into areas improved by aerial introduction of clover in the moister regions,

Overdrilling of cereals into tussock grasslands to provide greenfeed has already passed the early experimental stage, and in areas with suitable rainfall it should help to alleviate one of the most critical stages in existing run management.

It should be stressed, too, that overdrilling is the only satisfactory method of introducing lucerne where it is not desired to prepare an orthodox seedbed by cultivation.

\section{Plant Introduction}

Particularly for the depleted areas, thoughts for improvement 
centred for a long time on the introduction and establishment of new or improved species and strains of plants.

At the nursery maintained by the Department of Agriculture for many years at. Pisa Flat about 3.50 species or strains were tested and only five found to be adapted to that dry environment. Even they were not very successful when tried in the field. Similar disappointing results were obtained in other areas. One wonders now how much of the disappointment was due to the rabbit and to the lack of fertility. It is encouraging that K. F.

O'Connor has commenced, and will gradually extend, plant testing with a wide range of material (some standard lines, some new strains) in a wide variety of environments and at altitudes up to $4,600 \mathrm{ft}$ at least.

Fortunately we know so much about the performance of exist' ing material (especially white clover and cocksfoot) that, provided we are prepared to supply the necessary fertility elements, there is no need to delay improvement while awaiting for speciallybred material for introduction,

There are large areas of tussock grassland in the low to medium altitude zones where effective soil moisture is low and tolerance of drought is a primary requirement of plant survival. For such areas indications are that lucerne can prove a more useful legume than' white clover. Lucernes such as Marlborough can be successfully established in pockets of better soil (some properties have up to 900 acres), but for large-scale sowing it is possible that better survival can be obtained by using creepingrooted lucernes which have ability to colonise by spreading from the parent plant.

C. E. Iversen at Lincoln College, financed in part by the Tussock Grasslands and Mountain Lands Institute, has produced a strain which appears to have the ability to creep and to survive winter heaving and to have a season of growth considerably prolonged compared with that of Heinrich's Canadian strain. Testing of this strain is now being carried out under a wide variety of conditions at Molesworth, in the Mackenzie, and in Otago.

\section{What do Sheep Eat?}

In the tussock grasslands over 200 indigenous species and some 50 adventives have been recorded. Up to 50 species may occur on a face or on a valley floor.

Advances in basic knowledge as to what sheep eat are possible as a result of techniques developed by the Hercus family. With information obtained from use of these techniques it is possible 
to identify the species eaten by sheep at any time of the year. It should then be possible, by studying factors influencing growth and regeneration of these species, to develop a management system aimed at favouring them.

Barbara Hercus (1959) has applied to New Zealand conditions a method of cuticle analysis developed in Scotland. The method, based on the use of faecal samples and a set of references slides made from species growing in the area studied, gives qualitative results for any kind of animal feeding on any type of vegetation. It has the great advantage that there is no interference with the ordinary habits of the animals concerned.

J. M. Hercus (1963) uses a 12-inch ring dropped at predetermined intervals along a series of traverses. The observer records all the species occurring within the ring, examines each closely, and, using a numerical scale, rates them according to the intensity of grazing.

\section{Management}

The landholder himself has been a major agent in developing improved systems of management. The increased attention given to the spelling of blocks to permit reseeding (aided by subsidies for conservation fencing), the use of cattle to control rank growth (aided by conservation subsidies for cattle-proofing fences), and the growing of alternative feed (aided by conservation subsidies) to permit spelling or destocking of eroded land, are all important advances, even though they may, in turn, have brought new problems.

Catchment boards have been vitally interested in the effects of management on cover. Some of them, concerned that little or no factual information was available as to what really was 'happening to the vegetation, have set up line transects and exclosure plots in a wide variety of situations. Most extensive of these investigations have been those of the North Canterbury Catchment Board. Their Chief Soil Conservator, R. D. Dick, in a personal communication, has stated that since work was begun in 1947, 60,000 points have been recorded each year as to bare ground and living or dead vegetation.

Results to 1962 show that on all line transects under grazing (and these run up to $4,550 \mathrm{ft}$ ) bare ground is increasing. On enclosed plots (the highest is at 3,250 ft) bare ground is gradually being covered by vegetation. Studies of this kind are basic to improvements in management.

Connor's work on the development and growth of flowering stems of plants of the tussock grasslands (Connor 1963) is an 
important advance on which improved techniques of management could be based. From the time when the flowering heads are formed (and they are then less than one-tenth of an inch long) to the time of full development of the seed head there is a long period when the seed heads are liable to damage by grazing, trampling, or burning. "The timing therefore of animal management is important for plant management" where spelling is necessary to ensure maximum seed fall for regeneration.

Also on the theme of management J. M. Hercus (1961) has shown on depleted land in Central Otago how a knowledge of what are the really useful species, and what they require for good growth and satisfactory seed production, can suggest alterations in management which will hasten improvement. Complete spelling at a critical stage of growth just three to five weeks earlier than is usual in run practice produced spectacular results as far as regeneration was concerned, both through re-seeding and the better growth of parent plants. He has offered a guiding principle in utilisation: -"Avoid grazing the same block at the same time in the growing season every year, and the most critical time is in late spring and early summer." Fortunately the improvement work going on with seeding and topdressing provides extra fodder which must be utilised at the very time native pastures should be spelled for regeneration.

\section{Burning}

To burn or not to burn has long been a difficult question facing many occupiers of tussock grassland, Opinions still differ -in fact they may vary as much as the tussock grassland itself varies. But most observers would agree that a major advance has been the reduction of burning, in some areas and its complete cessation in others.

The rabbit stopped the practice over a wide area-he left nothing to burn. Observation by the runholder resulted in the practice being stopped or reduced elsewhere. New practices of grazing management, especially the increased use of cattle, showed that burning might profitably be dispensed with. By-laws of catchment authorities, sympathetically administered, have done their part as shown by Anderson (1962).

The provision of subsidy by the Soil Conservation and Rivers Control Council for the construction by catchment authorities of strategic firebreaks has helped considerably in the planning of burning control and in preventing accidental fires from becoming conflagrations.

Barbara Hercus (1962) over six years has evolved and tested a practical method of obtaining detailed effects of fire on the 
botanical composition of tussock grassland. Her results to date ' show that "the method does give a reasonably unbiased picture of the changes that occur after burning," but also stress how complicated the issue can be: "Every burn is' different; nine burns are under observation and on each site there are differences in the recovery pattern."

Where burning is considered necessary there would seem to be increasing application of the simple rule offered in 1958 by K. F. O'Connor to apply to all decisions on burning tussock grasslands: "No burning without replacement." He explained this further as: "If vegetation recovered from fire to give a complete ground mantle before there was a chance of erosive forces like heavy rainstorms or frost, then burning could be justified on land' suited for pastoral use and not required for critical water storage. Likewise, if burning was to be followed by topdressing and oversowing, with the reliable expectation that an effective cover to the ground surface could be obtained within one growing season, burning could be justified."

O'Connor (1962a and 1963a) has subsequently justified his rule by research work in the Mackenzie 'Pass, "the first occasion on which burning has been compared with no-burning in a controlled and replicated experiment on snow tussock". The results published in these papers provide us with a firm basis for any further advance in the study and control of burning.

\section{The Grazing Animal}

It is surprising that so little attention has been paid by research workers to the breeding, feeding, management, and improvement of sheep in the tussock grasslands. This deficiency has been corrected recently in some measure by I. E. Coop and V. R. Clark of Lincoln College. Financed by the Tussock Grasslands and Mountain Lands Institute, they are studying the performance of several thousand individual sheep on two Merino and two half-bred runs in Canterbury. Investigations are still in the early stages, but indications are that lambing percentage and the percentage of dry ewes are related to the weight of the ewe at tupping. It is believed that the work will stress the importance of feeding young stock well and the possible need for changes in the management of ewes. It appears that the live weight of the ewe must be increased in early life and then maintained.

Animal research is particularly difficult without complete control of the livestock and their management. It is fortunate therefore that the Tara Hills property of the Soil Conservation and Rivers Control Council has, since 1961, changed its emphasis and is now primarily a research station. On this property of 8,250 
acres investigations are being made by staff of the Department of Agriculture into such projects as planes of winter feeding, effect on lambing percentages of pre-tupping shearing of twotooths, early weaning of lambs, and grazing habits and performance of different breeds of sheep.

\section{Soil Fertility}

As in recent years much attention has been paid at these conferences to soil fertility and as it was also widely discussed at the meeting of the International Society of Soil Science here last year, I propose to be brief out of all proportion to its importance.

The great advance in mechanical aid, the use of the aeroplane, has already been mentioned. From the point of view of nutrient deficiency, the discovery of the vital importance of sulphur in the establishment and maintenance of legumes in tussock grassland, from Marlborough to Southland, altered our thinking and changed our practices (for example, Lobb and Bennetts 1958).

Present advice by the Farm Advisory Division, Department of Agriculture, as summarised in the Tussock Grasslands and Mountain Lands Review No. 4, March 1963, is the result of some hundreds of plot trials with clovers treated with sulphur and phosphorus, separately and in combination, and with and without molybdenum. Where finance is available and suitable fertilisers are applied little difficulty is now experienced in the lower and mid-altitude tussock grasslands in establishing clovers either by aerial sowing or, in semi-arid areas, by overdrilling.

For the explanation of many of the factors involved we owe much to Walker and his co-workers at Lincoln College (e.g. Walker and Adams 1958, 1959, Walker 1960). Of particular value has been their study of sequences of tussock grassland soils based on the genetic classification of the Soil Bureau. Ludecke's paper at this conference last year (1962) illustrated the practical, advice available from this type of study. Perhaps the next advance in this field will be the general planning of field trials on a basis of soil sequences.

Another contribution by Walker has been his provision, sponsored by the Institute, of "kit sets" of clover seed, inoculant, and fertilised materials to enable tussock farmers to establish their own indicator trials when a programme of improvement is proposed.

Mention only is possible of the work of O'Connor (1959, 1961, $1962,1963 b)$ in the field of soil fertility in difficult environments. 
Success in the establishment of legumes by correction of soil deficiencies has been shown by increased wool weights, more and healthier stock carried, more surplus stock sold, increased lambing percentages, more vigorous grasses (both native and introduced), better cover, and reduced run-off and soil loss.

Space permits only one example, that of Te Akatarawa, a property of 32,000 acres in the Waitaki Valley. Sheep numbers have risen only from 6,500 in 1942 to 8,300 in 1962, but cattle have risen from none to 420 over the same period. The wool clip amounted to 101 bales in 1942 and 176 bales in 1952. This increase reflected the control of the rabbit. In 1952 seeding and topdressing commenced and by 1959 3,000 acres had received a total of $2 \mathrm{lb}$ of clover seed and $5 \mathrm{cwt}$ of fertiliser per acre. Topdressing had to cease in 1959 to allow the cattle numbers to increase sufficiently to control the herbage. It will recommence in 1964. In 1962252 bales of wool and 2,000 head of surplus stock were sold.

\section{Conclusion}

The advances mentioned (and others which I have not been able to touch on) have helped to meet the challenge of the lower tussock country and to a large extent of the mid-altitude steeplands. They have resulted in our taking a new and -more hopeful view of the problems facing the tussock grasslands, provided always that a reasonable margin between costs and returns can be maintained.

, Basically the answers to improvement of tussock grasslands at the low and middle altitudes remain the same as were given by K. F. O'Connor to the 1958 conference of this organisation:

"1. Build fertility by adequate topdressing of the right kind and quantity.

" 2 . Introduce plants that can utilise the higher fertility and can be used by animals.

"3. Maintain the plant population and the built-up fertility by turning round the pasturage through the organic cycle of the grazing animal."

As a follower of Kelsey I would add "and treat adequately with DDT".

The challenge of the high-altitude tussock grasslands is still before us.

\section{References}

Anderson, G. A., 1962: Observations on burning control in Northern Otago. Proc. Sect. P (Conservation) 10th N.Z. Sci. Con. 32-39. 
Barker, A. P., 1953: An Ecological Study of Tussock Grassland. N.Z. Dep. Sci. Ind. Res. Bull. 107. 55 pp.

Connor, H. E., 1960: Some Aspects of the Botany of the Tussock Grasslands. Proc. 10th Lincoln Coll. Farm Conf. 78-81.

, 1961: A Tall-tussock Grassland Community in New Zealand. N.Z. J. Sci. 4:825-835.

1963: Growth of Flowering Stems in Five New Zealand Tussock Grasses. N.Z. J. Bot. 1:149-165.

Cutler, E. J., 1962: Soil-capability Classification Based on the Genetic Soil Map. Trans. Joint Mtg. Comm. IV and V. Int. Soc. Soil. Sci. 743-748.

Dunbar, G. A., 1962; Land Use Capability Patterns in Canterbury. Proc. Sect. P (Conservation) 10th N.Z. Sci. Cong. 5:18-21.

Gradwell, M. W., 1962: Physical Properties and Instability in South Island High Country Soils. Proc. N.Z. Soc. Soil Sci. 5:18-21.

Hercus, Barbara H., 1959: A Method of Estimating the Botanical Composition of the Diet of Sheep: N.Z. J. Agric. Res. 2:72-85

- 1962- Method of Studying Botanical Changes that Follow Burning on Tussock Grassland. N.Z. J. Agric. 104:190-194.

Hercus, J. M., 1961: Tussock Grassland Improvement by Grazing Management. N.Z. J. Agric. 103:257-261

, 1963: Botanical Sampling as a Means of Identifying the Components of Sheep's Diet in Tussock Grassland. N.Z. J. Agric. Res. 6:83-89.

Kelsey, J. M., 1957: Insects Attacking Tussock. N.Z. J. Sci. Tech. A 38:638-643.

Leamy, M. L., 1962: The Correlation of Soil Classification and Soil Capability in the Upper Clutha Valley, Otago, New Zealand. Trans. Joint Mtg. Comm. IV and V Int. Soc. Soil Sci. 749-754.

Lee, K. E., 1959: The Earthworm Fauna of New Zealand. N.Z. Dept. Sci. Ind. Res. Bull. 130, 486 pp.

Lobb, W. R., Bennetts, R. L., 1958: Improvement of Tussock Grassland in Canterbury. N.Z. J. Agric. 96:537-549.

Ludecke, T. E., 1962: Formulation of a Rational Fertiliser Programme in Tussock Country. Proc. 24th Conf. N.Z. Grassl. Assn. 29-41.

Mark, A. F., 1962: Zonation of Vegetation and Climate on the Old Man Range, Central Otago. Otago Univ. Sci. Record, 12:5-8.

O'Connor, K. F., 1959: Plant Production in Difficult Environments. Proc. N.Z. Inst. Ag. Sci. 5:86-94.

1961: Nitrogen in Grassland Production in the Mid-altitude Zone of Canterbury, New Zealand. Parts I, II, III. N.Z. J. Agric. Res. 4:686721.

1962a: The Role of Burning and Topdressing in Snow-tussock Management. Tussock Grasslands and Mountain Lands Institute Review. 3:17-26.

,1962b: Field Experimental Assessment of Fertility in Soils of the High Country of South Island, New Zealand. Trans. Joint Mtg. Comm. IV and V. Int.Soc. Soil. Sci. 691-697.

1962c: Success and Failure in the Culture of Mountain Soils. Proc. N.Z. Soc. Soil Sci. 5:31-38.

O'Connor, K. F.; Alison, J. Powell, 1963a: Studies on the Management of Snow-tussock Grassland I. N.Z.J. Agric. Res. 6:354-367.

O'Connor, K. F., 1963b: The Establishment of Grasses in Humid Tussock Grassland Regions. Tusssock Grassland and Mountain Lands Institute Review 5:20-24.

O’Connor, K. F.; Robinson, J. B.; Jackman, R. H., 1962: Bacterial Con- 
ditions and Nutrient Availability in a Tussock-Grassland Soil under Different Cultural Treatments. Trans. Joint Mtg. Comm. IV and V. Int. Soc. Soil Sci., 177-182.

Riney, T. A.; Dunbar, G. A., 1956: Criteria for Determining Status and Trend of High Country Grazing Lands in the South Island of New Zealand. Soil Conservation and Rivers Control Council. 32 pp.

Robinson, J. B., 1962: Studies on the Aerobic Bacterial Flora of a New Zealand Tussock Grassland Soil. (A thesis presented for the degree of Ph.D. Univ. of Canterbury.)

Stockdill, S. M. J., 1959: Earthworms Improve Pasture Growth. N.Z. J. Agric. 98:227-233.

Taylor, N. H.; Cox, J. E., 1956: The Soil Pattern of New Zealand. Proc. N.Z. Inst. Agric. Sci. 28-44.

Taylor, N. H.; Pohlen, I. J., 1962: Soil Survey Method. N.Z. Soil Bureau Bull. 25. 242 pp.

Tussock Grassland Research Committee. 1954. The High-altitude SnowTussock Grassland in South Island, New Zealand. N.Z. J. Sci. Tech. A 36:335-364.

Walker, T. W., 1960: Soil Fertility and Herbage Productivity. J. Brit. Grassl. Soc. 15:74-80.

Walker, T. W.; Adams, A. F. R., 1958a: Studies on Soil Organic Matter I. Soil Sci. 85:307-3 18.

- 1958b: Competition for Sulphur in a Grass-clover Association. Plan; and Soil 9:353-366.

1959: Studies on Soil Organic Matter II. Soil Sci. 87:1-10

Warner, A. O., 1956: Rabbit Destruction in Central Otago. N.Z. Meat and Wool Boards Econ. Serv.' Bull. 2. 25 pp.

Zotov, V. D., 1963: Synopsis of the Grass Sub-family Arundinoideae in New Zealand. N.Z. J. Bot. 1:78-136. 